Coast. Eng. Res. Ct

MR 76.8

(AD-A028 275)

\title{
Diurnal Variations in
}

Visually Observed Breaking Waves

by
P.C. Pritchett

MISCELLANEOUS REPORT NO. 76-8 MAY 1976
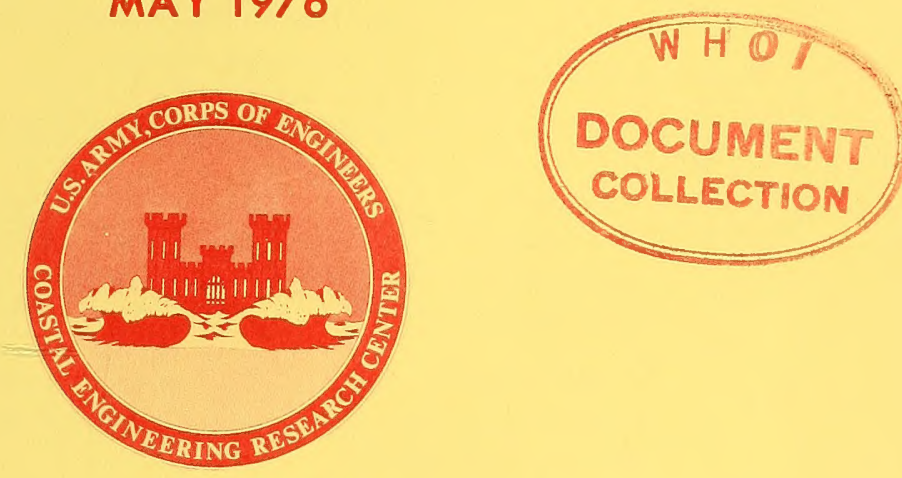

Approved for public release; distribution unlimited.

\section{U.S. ARMY, CORPS OF ENGINEERS \\ COASTAL ENGINEERING RESEARCH CENTER \\ Kingman Building \\ Fort Bolvoir, Va. 22060}

581 
Reprint or republication of any of this material shall give appropriate credit to the U.S. Army Coastal Engineering Research Center.

Limited free distribution within the United States of single copies of this publication has been made by this Center. Additional copies are available from:

National Technical Information Service
ATTN: Operations Division
5285 Port Royal Road
Springfield, Virginia 22151

Contents of this report are not to be used for advertising, publication, or promotional purposes. Citation of trade names does not constitute an official endorsement or approval of the use of such commercial products.

The findings in this report are not to be construed as an official Department of the Army position unless so designated by other authorized documents. 


\begin{tabular}{|c|c|}
\hline REPORT DOCUMENTATION PAGE & $\begin{array}{c}\text { READ INSTRUCTIONS } \\
\text { BEFORE COMPLETING FORM }\end{array}$ \\
\hline \begin{tabular}{l|l} 
1. REPORT NUMBER & 2. GOVT ACCESSION NO. \\
MR $76-8$ & \\
\end{tabular} & 3. RECIPIENT'S CATALOG NUMBER \\
\hline \multirow[t]{2}{*}{$\begin{array}{l}\text { 4. TITLE (and Subtitie) } \\
\text { DIURNAL VARIATIONS IN VISUALLY OBSERVED BREAKING } \\
\text { WAVES }\end{array}$} & $\begin{array}{l}\text { 5. TYPE OF REPORT \& PERIOD COVERED } \\
\text { Miscellaneous Report }\end{array}$ \\
\hline & 6. PERFORMING ORG. REPORT NUMBER \\
\hline $\begin{array}{l}\text { 7. AUTHOR(s) } \\
\text { P.C. Pritchett }\end{array}$ & 8. CONTRACT OR GRANT NUMBER(o) \\
\hline $\begin{array}{l}\text { 9. PERFORMING ORGANIZATION NAME AND ADDRESS } \\
\text { Department of the Army } \\
\text { Coastal Engineering Research Center (CERRE-CP) } \\
\text { Kingman Building, Fort Belvoir, VA } 22060\end{array}$ & $\begin{array}{l}\text { 10. PROGRAM ELEMENT, PROJECT, TASK } \\
\text { AREA \& WORK UNIT NUMBERS } \\
\text { A } 31463\end{array}$ \\
\hline \multirow{2}{*}{$\begin{array}{l}\text { 11. CONTROLLING OFFICE NAME AND ADDRESS } \\
\text { Department of the Army } \\
\text { Coastal Engineering Research Center } \\
\text { Kingman Building, Fort Belvoir, VA } 22060\end{array}$} & $\begin{array}{l}\text { 12. REPORT DATE } \\
\text { MaY } 1976\end{array}$ \\
\hline & 13. NUMBER OF PAGES 2120 \\
\hline \multirow{2}{*}{ 14. MONITORING AGENCY NAME \& ADDRESS(if different from Controlling Office) } & $\begin{array}{l}\text { 15. SECURITY CLASS. (of thls report) } \\
\text { UNCLASSIFIED }\end{array}$ \\
\hline & $\begin{array}{l}\text { 15a. DECLASSIFICATION/DOWNGRADING } \\
\text { SCHEDULE }\end{array}$ \\
\hline
\end{tabular}

Approved for public release; distribution unlimited.

17. DISTRIBUTION STATEMENT (of the abstract entered in Block 20, $1 f$ different from Report)

18. SUPPLEMENTARY NOTES

19. KEY WORDS (Continue on reverse side if necessary and identify by block number)

Breaker height

Diurnal variations
Sea breeze-generated waves

Wave climate

20. ABSTRACT (Continue on reverse side if necosaary and identify by block numbor)

In over 53,000 visual observations made four times daily at 17 U.S. Coast Guard stations during June, July, and August, the average monthly diurnal variations in breaker height ranged from 0.05 to 0.36 foot; diurnal variations averaged about 10 percent of the monthly mean height. Stations along the gulf and in the Pacific Northwest showed the most diurnal variations. Stations with good exposure had smaller absolute diurnal variations in height than stations with limited exposure. Absolute diurnal variations were also small at 
stations with large mean breaker heights. An approximation of the height that combines the swell and sea breeze-generated waves provides an indication of why observed variations were small. 


\section{PREFACE}

This report is published to provide coastal engineers a semiquantitative idea of the occurrence of sea breeze-generated waves on the Atlantic, Pacific, and gulf coasts of the United States. The work was carried out under the coastal processes program of the U.S. Army Coastal Engineering Research Center (CERC).

Most of the data for this report were collected under a cooperative program between the U.S. Coast Guard and CERC. Visual wave observations were made at selected stations on the Atlantic, Pacific, and gulf coasts by U.S. Coast Guard personnel, and at two gulf coast stations by volunteer observers. The information was processed and analyzed by CERC.

The report was prepared by P.C. Pritchett, while at CERC, under the supervision of C.J. Galvin, Jr., Chief, Coastal Processes Branch, Research Division.

The author acknowledges the time and effort spent by the Coast Guard and other volunteer observers.

Comments on this publication are invited.

Approved for publication in accordance with Public Law 166, 79th Congress, approved 31 July 1945, as supplemented by Public Law 172, 88th Congress, approved 7 November 1963.

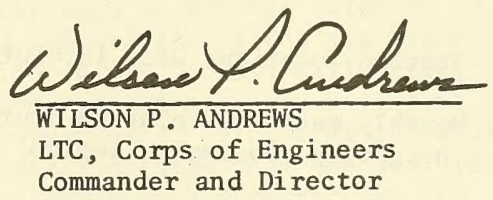


I SEA BREEZE. . . . . . . . . . . . . . . . . 5

II WAVE DATA ............... . . 6

III VARIATIONS BY MONTH AND LOCALITY. . . . . . . . . . . 6

IV CURVE ClASSIFICATION. . . . . . . . . . . . . . 10

V EXPOSURE AND ANNUAL HEIGHT. . . . . . . . . . . . . 16

VI EST IMATED BREAKER HEIGHTS . . . . . . . . . . . . . 17

VII COASTAL ENGINEERING APPLICATIONS. . . . . . . . . . . 18

VIII SUMMARY . . . . . . . . . . . . . . . . . . 19

LITERATURE CITED. . . . . . . . . . . . . . 20

\section{TABLES}

1 Curve group number for D-ratio wave height curves. . . . . . 15

2 Absolute diurnal variation for coastal exposure groupings. . . 16

3 Absolute diurnal variation for breaker height groupings. . . . 17

4 Observed and approximated wave heights for selected stations in July . . . . . . . . . . . . . . . . . . 18

\section{FIGURES}

1 Station locations used in diurnal study. . . . . . . . . . . 7

2 Monthly means of relative diurnal variation, $\Delta \mathrm{D}$, in breaker height by geographic region . . . . . . . . . . . . . 9

3 Absolute and relative diurnal variation in breaker height by latitude grouping ................... . . 11

4 Absolute and relative diurnal variation in breaker height by geographic grouping . . . . . . . . . . . . . . 12

5 Representative curves for $D_{j}$ curve groups. . . . . . . . . . . . 14 
Local diurnal winds occurring along a coastline as a result of different 1 and and water temperatures are called Zand and sea breezes. The land breeze blows during the night from land to sea and is weaker than the sea breeze, which blows from sea to land during the day. Observations of these phenomena are probably as old as the original settlement of the coasts, and their existence has been reported in all coastal areas except the Arctic. One of the earliest reports on the sea breeze (Davis, Schultz, and Ward, 1890) discussed the mechanism that produces sea breeze, and gave an account of a volunteer observer program studying the phenomenon (observed on 30 days of a 3-month period) in Massachusetts.

Depending on prevailing pressure patterns, the sea breeze may form at the shoreline and advance inland in a series of pulsations (Wallington, 1960), or the sea breeze may form offshore and then advance toward the shoreline and inland (Wexler, 1946).

The frequency of sea breeze occurrence, which depends on latitude, season, and other factors, was estimated to be 30 to 40 percent in the summer for the eastern coast of the United States (Wexler, 1946).

Although the typical characteristics of the sea breeze can be modified by prevailing circulation patterns (Moroz, 1967), the typical sea breeze varies from 1 to 7 hours in duration, and has maximum wind gusts of 30 knots. In the midlatitudes, maximum speeds are about 20 knots, and the mean speed is about 10 knots.

Vertical height of the sea breeze ranges from 1,000 to about 3,000 to 4,000 feet (Byers and Rodebush, 1948). Although an average value of 20 to 25 miles has been estimated for inland penetration of the sea breeze, up to 200 miles was reported in the tropics (Clarke, 1961; Wallington, 1961). However, because of the lack of observation stations little is known about the seaward extension of the sea breeze. Findlater's (1963) report on aircraft studies of the sea breeze indicated that the sea breeze was noticeable 10 to 12 miles out to sea. Hsu (1970) detected the sea breeze 18 miles offshore of the Texas coast.

Although the sea breeze generally has a low windspeed and a short fetch, the sea breeze does have some effect on waves, e.g., a windspeed of 10 knots blowing over a 10 -mile fetch would result in a 1.25 -foothigh wave with a 2.4-second period (U.S. Army, Corps of Engineers, Coastal Engineering Research Center, 1975). Waves of these dimensions, even when superimposed on a higher and longer period swe11, could be visually observed or detected in gage records. Harris (1972) commented on the existence of a diurnal cycle of wave heights in gage data (see also Esteva, 1972). The Coastal Studies Institute of Louisiana State 
University is also examining wave data collected during sea breezes (Sonu, et a1., 1973).

This study describes the effect of sea breeze on the coastal wave climate, as delineated by several years of visual wave observations in the different geographic regions and latitudes of the United States, and correlates the variations in wave height and period to the coastal exposure and geographic features of various observation stations.

\section{WAVE DATA}

Most of the wave data in this study were visual observations from a cooperative effort of the U.S. Coast Guard and the Coastal Engineering Research Center (CERC) (Cooperative Surf Observation Program, COSOP). Exceptions were the visual observations from Crystal Beach Pier in Destin, Florida, and Grayton, Florida. The data were handwritten on forms by the observers and then transferred to cards and magnetic tapes. The names, locations, and dates of record for the COSOP stations are shown in Figure 1. COSOP data collected before January 1955 or after December 1965 were not used in this study.

Wave height, direction, period, and breaker-type were reported as frequently as every 4 hours from COSOP stations along the Pacific, gulf, and Atlantic coasts (Darling, 1968). Wave height is reported to the nearest foot, and period is reported as the time (seconds) it takes for 11 breaker crests to pass a point.

Previous examination of COSOP data has resulted in the conclusion that the data are consistent with known climatological conditions, and internally consistent in that most neighboring stations with similar exposure produce about the same average values of the variables (Galvin, et a1., 1969; Galvin, Tenney, and Seelig, 1970). However, individual observations at most stations may be questionable, and at some stations the mean values appear to be wrong. COSOP statistics in the form of monthly and yearly means by station were compiled by Galvin and Seelig (1969).

The wave data from Crystal Beach Pier and Grayton State Park were taken twice daily by volunteer observers. Wave height from these two locations was estimated to the nearest one-half foot.

\section{VARIATIONS BY MONTH AND LOCALITY}

Monthly averages of height were used to calculate a ratio, $D_{j}$, which is defined as:

$$
D_{j}=\frac{\bar{x}_{j}}{\bar{x}},
$$




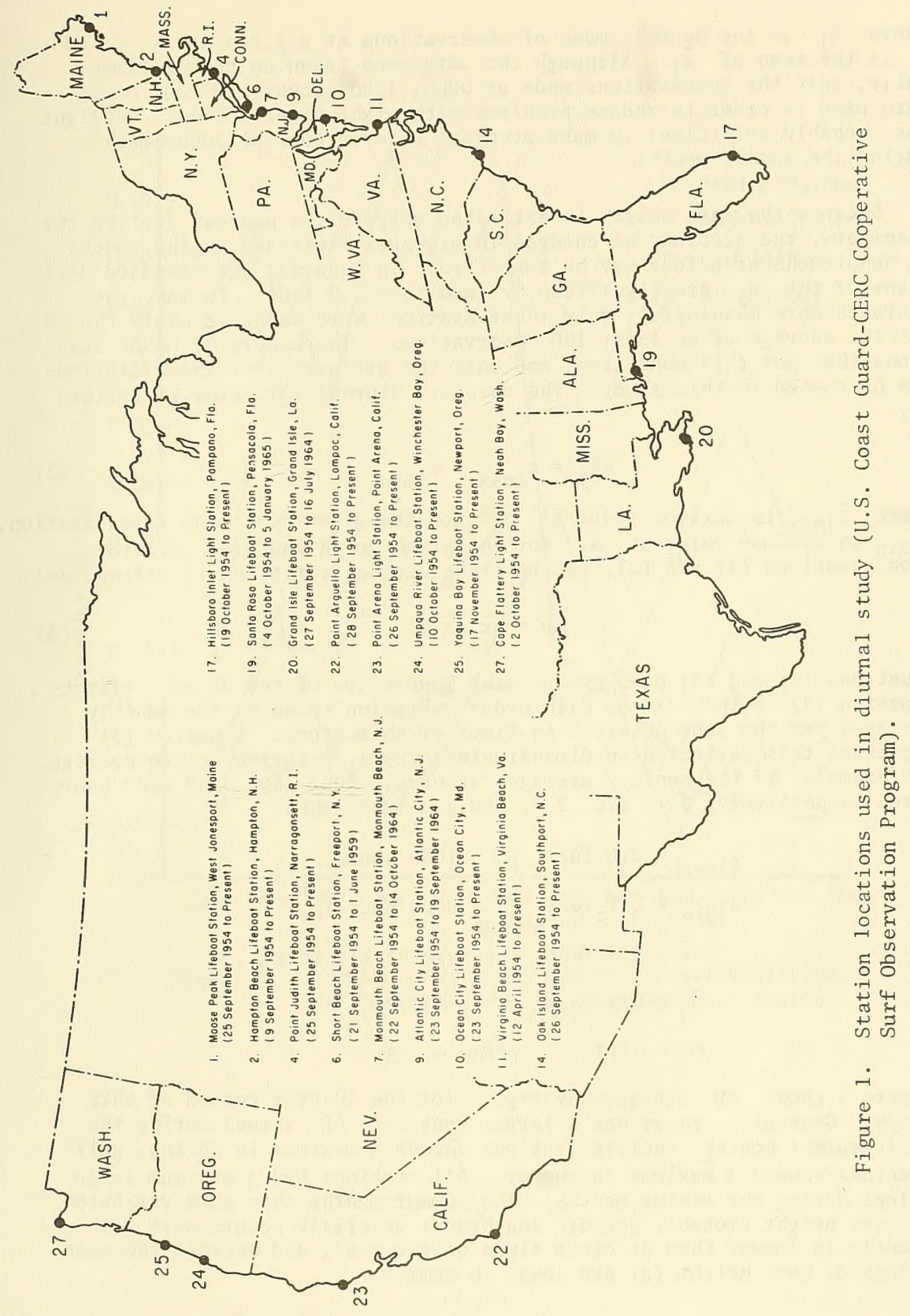


where $\bar{x}_{j}$ is the month1y mean of observations at a given hour, $j$, and $\bar{x}$ is the mean of $\bar{x}_{j}$. Although the data were taken up to six times daily, on $1 y$ the observations made at $0800,1200,1600$, and 2000 hours were used in order to reduce problems with night observations. Daylight was probably sufficient to make accurate observations at 2000 hours during the summer months.

Because the wave height is estimated only to the nearest foot by the observers, the accuracy of changes in averages expressed to the tenths or hundredths of a foot may be suspected. In general, the standard deviations of the $\bar{x}_{j}$ are significantly less than 1.0 foot. To make the averages more meaningful, only those stations were selected where the $\bar{x}_{j}$ was the average of at least 100 observations. There were 17 COSOP stations that met this condition, and only the averages from these stations are discussed in this study. The absolute diurnal variation is defined as :

$$
\Delta \bar{x}_{j}=\bar{x}_{j \max }-\bar{x}_{j \min }
$$

where $\bar{x}_{\text {jmax }}$ is maximum value of $\bar{x}_{j}$ for the given month and given station, $\bar{x}_{j m i n}$ is minimum value of $\bar{x}_{j}$ for the given month and given station. From equations (1) and (2), the relative diurnal variation is defined as:

$$
\Delta \mathrm{D}=\Delta \overline{\mathrm{x}}_{\mathrm{j}} / \overline{\mathrm{x}}
$$

Equations (2) and (3) both measure the importance of the diurnal effect. Equation (2) is the maximum within-day variation shown by the monthly averages for the four observation times of this study. Equation (3) expresses this variation in dimensionless terms, relative to the average. For example, if the monthly averages at $0800,1200,1600$, and 2000 hours were, respective $1 y, 2.2,2.5,2.6$, and 2.3 feet, then

$$
\begin{aligned}
& x_{j \max }=2.6 \text { feet }(j=1600 \text { hours }) \text {, } \\
& x_{j \min }=2.2 \text { feet }(j=0800 \text { hours }) \text {, } \\
& \bar{x}=2.4 \text { feet (average of all four), } \\
& \Delta \bar{x}_{j}=0.4 \text { foot (from eq. 2), } \\
& \Delta D=0.17 \quad \text { (from eq. 3). }
\end{aligned}
$$

Figure 2 shows $\Delta D$ averaged by region for the 10-year period of this study. Generally, there was a larger range of $\Delta D$ values during the early summer months; Pacific stations showed a maximum in spring; gulf stations showed a maximum in summer. All stations had a minimum in $\triangle \mathrm{D}$ values during the winter months. The summer months show more variation in wave height probably because sea breeze generally occurs more frequently in summer than at other times of the year, and because the mean values of wave height $(\bar{x})$ are lower in summer. 


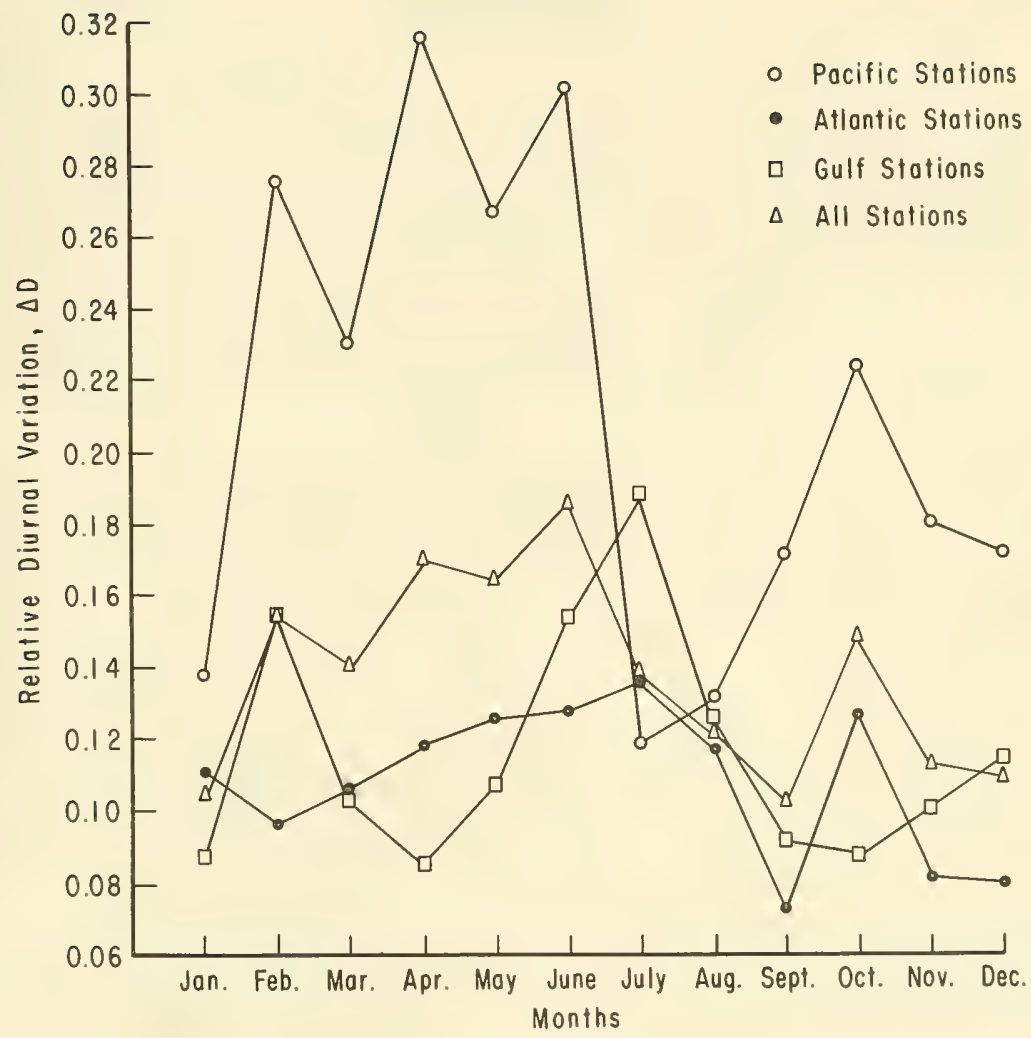

Figure 2. Monthly means of relative diurnal variation, $\Delta \mathrm{D}$, in breaker height by geographic region. 
Figure 3 shows a comparison of two expressions of the diurnal variation: The mean range of the ratios, $\Delta D$, called relative diurnal variation, and $\bar{x}_{j m a x}-\bar{x}_{j m i n}$, called the absolute diurnal variation, averaged for stations grouped by latitude during the months of June, July, and August. Figure 4 shows the same comparison for stations grouped by geographic region.

The amount of absolute diurnal variation, $x_{j m a x}-x_{j m i n}$, was high in the Pacific Northwest and along the gulf, and appeared to be the highest in the $25^{\circ}$ to $35^{\circ}$ latitude group. These relations correspond to what is qualitatively known about sea breeze frequency in these areas.

A study of gage records at Pt. Mugu, California, by Esteva (1972) resulted in the conclusion that daily variations in wave height are at a maximum from April to June. This roughly agrees with Figure 4 which shows that absolute variation for two stations in California is greater in June than in July or August.

Frequent occurrence of sea breeze has been reported for the gulf coast and the southern Atlantic regions (Hsu, 1970; Yu and Wagner, 1970; McPherson, 1970), and is supported by wind data in the gulf (CERC Littoral Environment Observations (LEO), unpublished; unpublished twice daily wind reports from the Crystal Beach Pier).

During May, June, and July 1972, wave observations were made twice daily at Crystal Beach Pier between 0530 and 0830 hours and between 1430 and 1630 hours. For 132 observations, the mean breaker height of the morning observations was 2.2 feet and the mean height of the afternoon observations was 2.3 feet. On 39 percent of the days the afternoon height was larger than the morning; on 23 percent of the days the morning height was larger than the afternoon height; on 38 percent of the days the morning and afternoon heights were equal.

At Grayton Beach State Park, Santa Rosa Beach, Florida, 15 miles east of Crystal Beach Pier, wave observations were made twice daily during May and June 1972. For 90 observations, the morning mean breaker height was 1.7 feet, and the afternoon mean was 1.9 feet. The afternoon heights were larger than the morning 47 percent of the days, smaller 24 percent of the days, and equal the remaining 29 percent of the days, which was in fair agreement with the data from Crystal Beach Pier.

\section{CURVE CLASSIFICATION}

The ratio, $D_{j}$ (eq. 1), for wave height during June, July, and August was plotted versus time of day for the 17 COSOP stations. The resulting curves, consisting of three lines connecting four points, are characterized by:

$$
D_{j \max }=1 \text { argest value on curve, }
$$




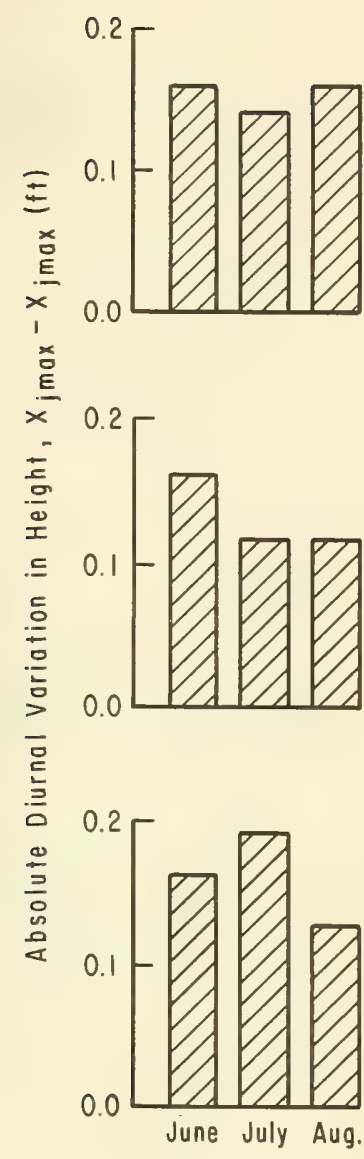

Above $40^{\circ}$
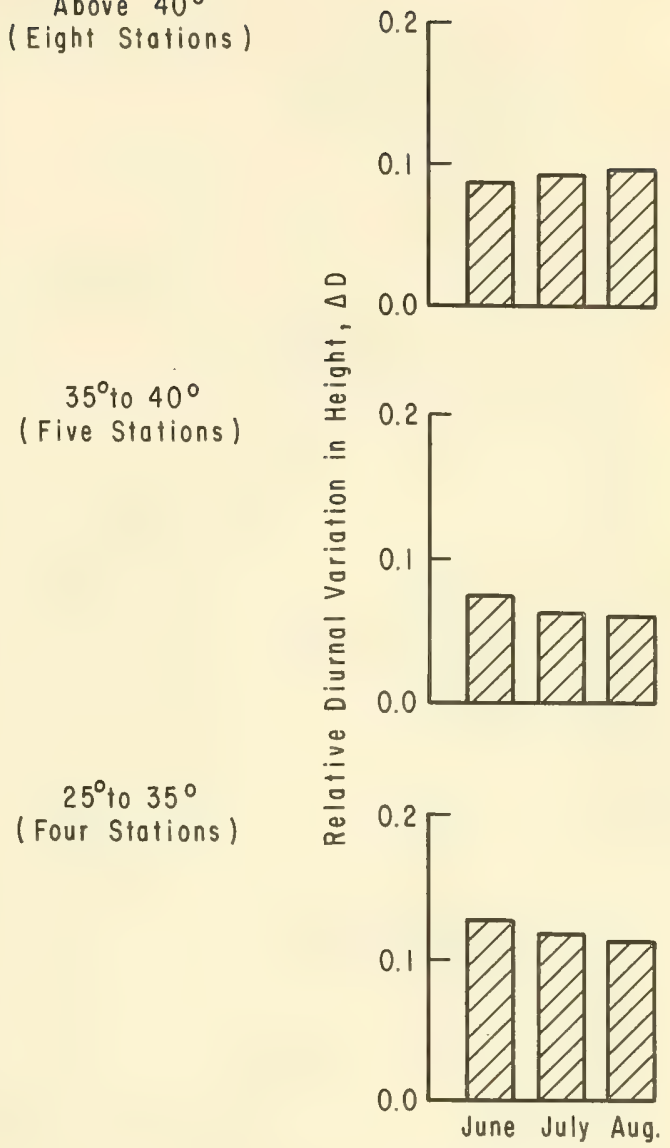

Figure 3. Absolute and relative diurnal variation in breaker height by latitude grouping. 


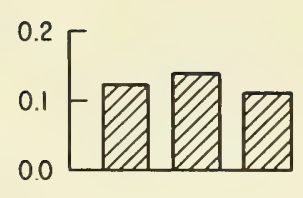

ATLANTIC NORTH

(Seven Stations)
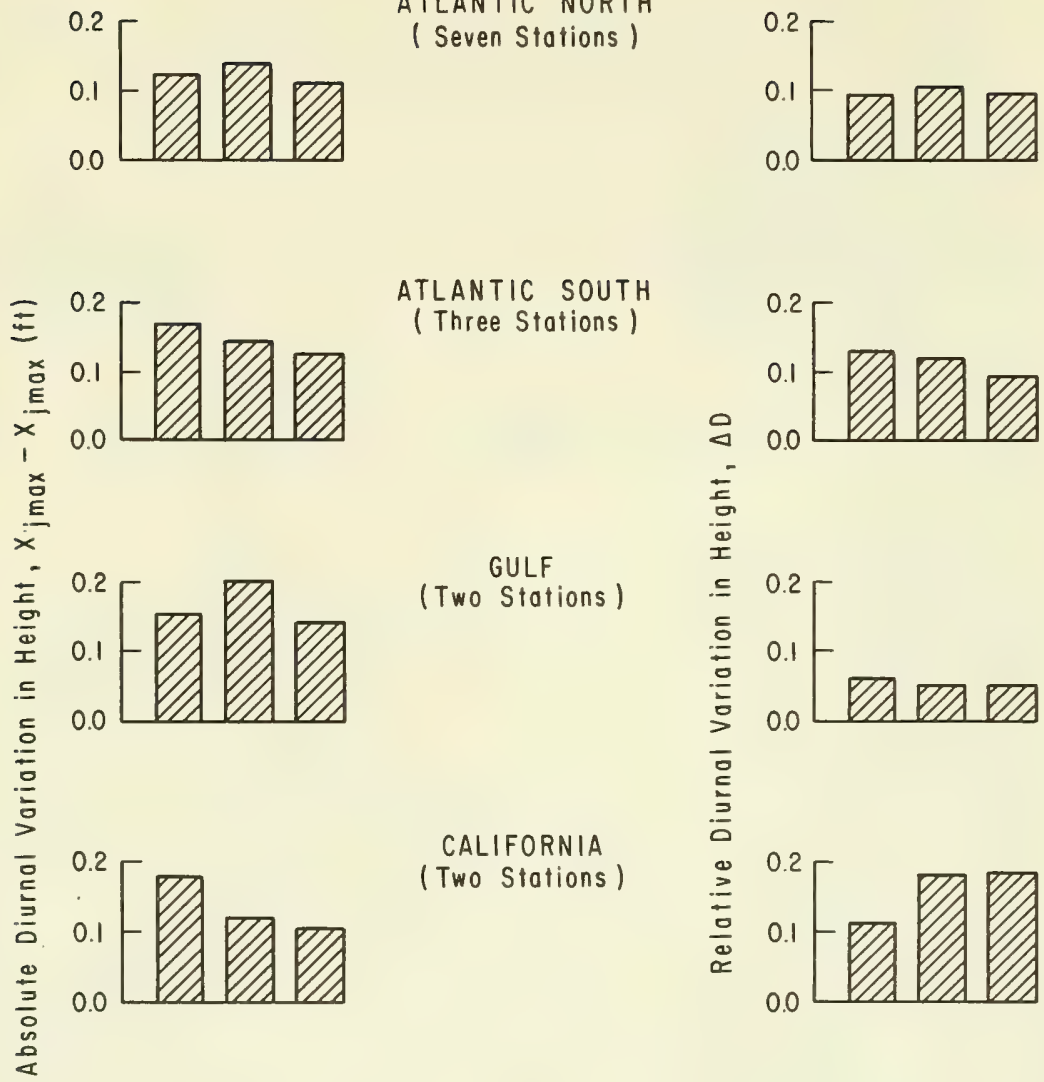

ATLANTIC SOUTH

(Three Stations)

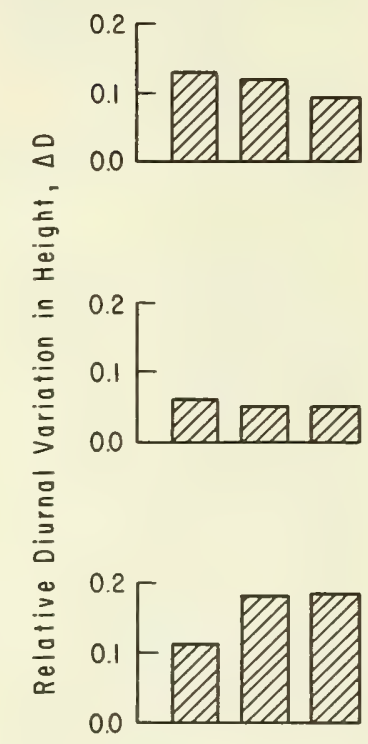

(Two Stations)

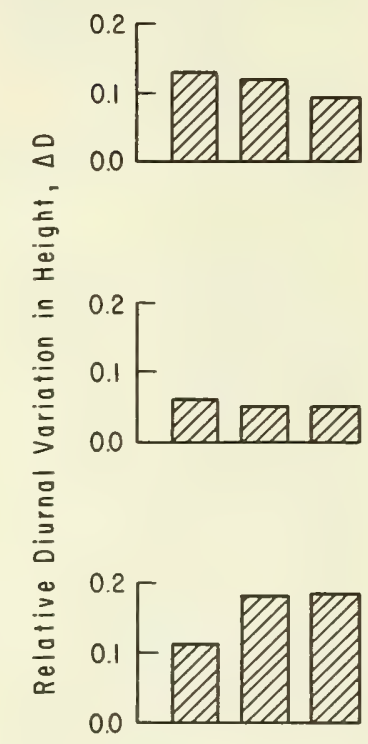

CALIFORNIA

(Two Stations)

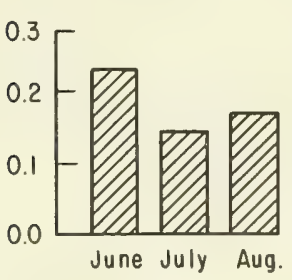

PACIFIC NORTHWEST

(Three Stations)

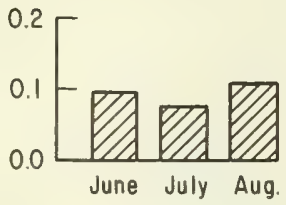

Figure 4. Absolute and relative diurnal variation in breaker height by geographic grouping. 
$\begin{aligned} D_{\text {jmin }}= & \text { smallest value on curve, and sometimes, } \\ D_{j s m}= & \text { secondary maximum; a value at least } 0.025 \text { greater } \\ & \text { than minimum values between it and } D_{\text {jmax }} .\end{aligned}$

The curves for each station were classified into six groups (Fig. 5) identified by numbers 1 to 6 :

(1) $D_{j \max }$ occurring at 1200 or 1600 hours; or at 2000 hours if the next highest point is at 1600 hours; $D_{j \max }-D_{j \min }>0.1$, and no $\mathrm{D}_{\mathrm{jsm}}$.

(2) Same as number 1 , except that $D_{j \max }-D_{j \min } \leq 0.1$.

(3) $D_{j \max }$ occurring at 0800 hours; or at 2000 hours, but only if the next highest point is not at 1600 hours; $D_{j \max }-D_{j \min } \leq 0.1$, and no $\mathrm{D}_{\mathrm{jsm}}$.

(4) Same as number 3 except that $D_{j \max }-D_{j \min }>0.1$.

(5) $D_{j \max }$ and $D_{j s m}$ both occurring.

(6) Anything that does not fit into groups 1 to 5 .

The curve groups classify diurnal variation by time of occurrence of maximum, occurrence of secondary maxima, and amount of variation between the highest and lowest values. The typical curves for the six-curve groups are shown in Figure 5. Curves resulting from an idealized landsea breeze system would fall into one of the first four groups. Groups 1 and 2 have a day or early evening maximum (expected for wave height); groups 3 and 4 have a morning or late evening maximum (possible for period distribution).

Wave height curve groups for each station in June, July, and August are listed in Table 1. Group 1 or 2 curves were found at 88 percent of the stations in June, 94 percent in July, and 82 percent in August. There does not appear to be any pattern to the exceptions.

As a check of significance, $100 \mathrm{D}_{j}$ curves of the types shown in Figure 5 were artificially generated by randomly choosing sets of four numbers from the pooled $D_{j}$ numbers found for summer months at the COSOP stations; 57 fell into groups 1 or 2 . This suggests that the approximately 88 percent occurrence of groups 1 or 2 actually observed was not a chance occurrence.

Groups 1 or 2 should be representative of the diurnal variation in wave height because the daytime onshore sea breeze should increase the height. The effect should be more significant where wave heights are normally quite low. The same onshore wind is expected to decrease the period by generating waves with shorter than average periods because of 


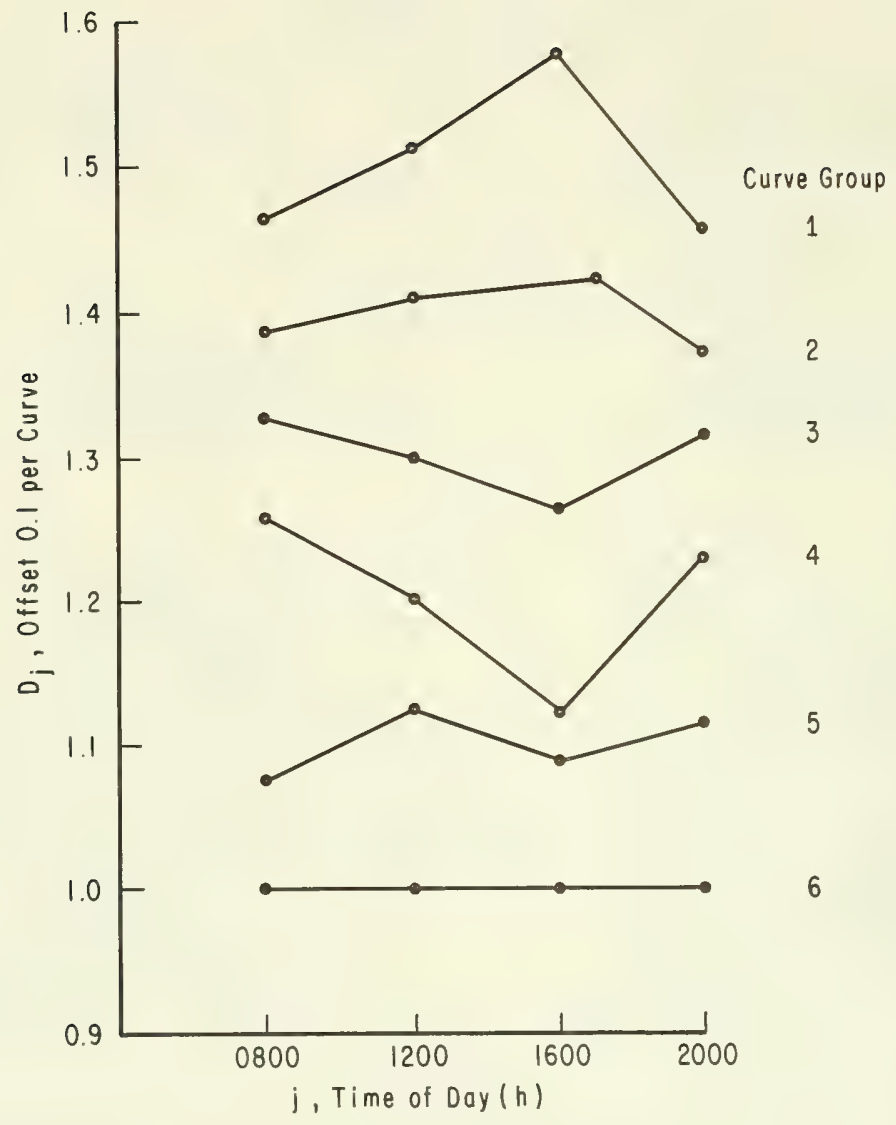

Figure 5. Representative curves for $D_{j}$ curve groups. 
Table 1. Curve group number for D-ratio wave height curves.

$\begin{array}{lll}\text { Station June July } & \text { Jugust }\end{array}$

number

Atlantic North

\begin{tabular}{rlll}
\hline 1 & 2 & 2 & 2 \\
2 & 3 & 1 & 1 \\
4 & 1 & 2 & 1 \\
6 & 2 & 2 & 5 \\
7 & 1 & 1 & 3 \\
9 & 4 & 1 & 1 \\
10 & 2 & 2 & 2 \\
\hline
\end{tabular}

Atlantic South

\begin{tabular}{llll}
\hline 11 & 1 & 2 & 2 \\
14 & 1 & 1 & 2 \\
17 & 1 & 1 & 5 \\
\hline & & Gulf & \\
\hline 19 & 1 & 1 & 1 \\
20 & 2 & 1 & 2 \\
\hline
\end{tabular}

California

\begin{tabular}{llll}
\hline 22 & 2 & 2 & 2 \\
23 & 2 & 2 & 2 \\
\hline
\end{tabular}

Pacific Northwest

\begin{tabular}{llll}
\hline 24 & 2 & 2 & 2 \\
25 & 2 & 3 & 2 \\
27 & 1 & 1 & 1 \\
\hline
\end{tabular}

1. Station locations of the U.S. Coast Guard-COSOP (Fig, 1). 
the limited fetch. However, the plots of the period ratios fell almost equally into groups 1 to 4 . Visual observation of the wave period is difficult, especially if more than one wave train is present. If the height of the swell is large, then the superimposed smaller sea breezegenerated waves may not be visible to the observer, and the shorter period waves would not appreciably alter the observed period of the swell, although it might add to the observed height.

\section{EXPOSURE AND ANNUAL HEIGHT}

The orientation and exposure of a station's coastline affect both the wave climate and the sea breeze. For this reason, the coastal exposure of the observing station was compared with the diumal variation in wave height for the 17 COSOP stations. Two measures of exposure were defined by measuring the size of the overwater arc swept by a 30- or 300-mile radius centered on the station. Small islands were ignored, and large islands were subtracted from the arc. The resulting sector, measured in degrees, was taken as the exposure of the station (Kohler, 1972). The COSOP stations were grouped in four categories by the size of the sector measured from National Ocean Survey charts, and the absolute diurnal variation in wave height was averaged for stations in each exposure category (Table 2).

Tab1e 2. Absolute diurnal variation for coastal exposure groupings. Exposure group Number of Mean absolute diurnal variation stations July June/July/August

$(\mathrm{ft})$

(ft)

\begin{tabular}{cccc}
\hline \hline 30 -mile land limited & 4 & 0.100 & 0.111 \\
$>180^{\circ}$ & 5 & 0.112 & 0.138 \\
$157^{\circ}$ to $180^{\circ}$ & 5 & 0.132 & 0.145 \\
$135^{\circ}$ to $156^{\circ}$ & 3 & 0.165 & 0.160 \\
$<135^{\circ}$ & &
\end{tabular}

\begin{tabular}{cccc}
\hline 300-mile land limited & & & \\
$>162^{\circ}$ & 2 & 0.115 & 0.132 \\
$126^{\circ}$ to $162^{\circ}$ & 7 & 0.137 & 0.145 \\
$90^{\circ}$ to $125^{\circ}$ & 4 & 0.168 & 0.164 \\
$<90^{\circ}$ & 4 & 0.133 & 0.113
\end{tabular}

The average absolute diumal variation for June, July, and August appears to depend on exposure (Table 2). As the 30-mile land-limited exposure increases, the absolute diumal variation decreases. The 300mile exposure shows a similar trend except for the group with minimum exposure. If the observed variations are directly related to the sea 
breeze, the sea breeze is apparently stronger at stations with poor exposure than at stations with more open exposure.

Mean absolute diumal variation for three breaker height groupings are presented in Table 3 . Stations with larger annual means tend to have less diurnal variation.

\begin{tabular}{cccc}
$\frac{\text { Table 3. Absolute diumal variation for breaker height }}{4} \begin{array}{c}\text { Annual mean } \\
\text { height group } \\
\text { (ft) }\end{array}$ & $\begin{array}{c}\text { Number of } \\
\text { curves }\end{array}$ & $\begin{array}{c}\text { Mean absolute diumal variation } \\
\text { July } \\
(\mathrm{ft})\end{array}$ & $\begin{array}{c}\text { June/July/August } \\
\text { (ft) }\end{array}$ \\
\hline \hline$<1.4$ & 2 & 0.160 & 0.130 \\
1.4 to 2.0 & 10 & 0.148 & 0.143 \\
$>2.0$ & 5 & 0.118 & 0.139 \\
\hline
\end{tabular}

\section{ESTIMATED BREAKER HEIGHTS}

For a windspeed of 10 knots blowing over a 10 -mile fetch (a typical sea breeze), a 1.25-foot-high wave having a period of 2.4 seconds might be expected (U.S. Army, Corps of Engineers, Coastal Engineering Research Center, 1975). An approximation of height, considering the frequency of occurrence of the sea breeze, would be

$$
\mathrm{H}_{\mathrm{p}}=\mathrm{f}_{\mathrm{SB}} \sqrt{\mathrm{H}_{\mathrm{SB}}{ }^{2}+\mathrm{H}_{\mathrm{S}}^{2}}+\left(1-\mathrm{f}_{\mathrm{SB}}\right) \mathrm{H}_{\mathrm{S}}
$$

where,

$$
\begin{aligned}
& \mathrm{H}_{\mathrm{p}}=\text { approximated height, } \\
& \mathrm{f}_{\mathrm{SB}}=\text { frequency of occurrences of the sea breeze, } \\
& \mathrm{H}_{\mathrm{SB}}=\text { height of sea breeze-generated wave, } \\
& \mathrm{H}_{\mathrm{S}}=\text { height of swell. }
\end{aligned}
$$

Equation (4) with $f_{S B}=0.40$, was used to estimate the effect of sea breeze on the mean observed height for selected stations in July (Table 4). The equation provides a plausible explanation of the small diurnal variation found in the monthly averages. Because the sea breeze does not occur every day, and because its effects are masked by superposition on the swell, the examples contained in Table 4 show that the effect of sea breeze on average conditions is small.

As shown in Table 4, the absolute variation increases with decreasing mean height of the waves (compare observed daily mean with approximated height in Table 4). If average wave conditions are low, the effect of the 
sea breeze will be greater than if average wave conditions are high. A sea breeze-generated wave will probably not appreciably alter the observed height of swell when the height is 3 feet or greater. This is expected from the form of equation (4).

Table 4. Observed and approximated wave heights

\begin{tabular}{llcc}
$\begin{array}{l}\text { Station } \\
\text { Number }\end{array}$ & $\begin{array}{c}\text { for selected stations in July. } \\
\text { Daily } \\
(\mathrm{ft})\end{array}$ & $\begin{array}{c}\text { Observed Mean } \\
\text { (ft) }\end{array}$ & $\begin{array}{c}\text { Approximated } \\
\text { height }\end{array}$ \\
\hline \hline 25 & 4.0 & 4.1 & 4.1 \\
19 & 1.2 & 1.3 & 1.4 \\
11 & 1.7 & 1.8 & 1.9 \\
2 & 1.2 & 1.3 & 1.4 \\
\hline
\end{tabular}

1. Station locations, U.S. Coast Guard-COSOP (Fig. 1)

2. Assuming superimposed waves from a 10 -knot sea breeze with a $10-$ mile fetch occurring 40 percent of the time (see eq. 4).

\section{COASTAL ENGINEERING APPLICATIONS}

This study indicates that a small but potentially significant increase in average wave height occurs when a sea breeze is present; the increase seems larger at stations in sheltered areas with poor exposure. This effect should be considered in analysis and interpretation of coastal and visual wave data. On the average the increase in height will be slight, as shown by the above analysis, but on a given day this increase may be important.

The data in this paper show that the sea breeze effect on wave climate varies with geographic region, coastal exposure, and time of year. This information can affect coastal engineering design in the following ways:

(a) Refining estimates of the amount of down time due to wave conditions near the coast. Sea breeze affects wave climate, usually during the summer in the later half of the daylight hours. This fact could improve planning for work boat activity along the coast, especially small working craft like survey launches which would be more affected by the short period of the sea breeze-generated waves.

(b) Improving the design of harbors. Many marinas and sma11-craft harbors have large enclosed expanses of water over which sea breeze could generate waves that damage small craft at their moorings. Consideration of sea breeze effects in planning may result in harbor layouts to reduce such effects. 
(c) Improved knowledge of wave climate. The effects documented in this paper, including the fact that some of the effects are surprisingly small, add to the store of wave climate information available for coastal engineering design.

\section{SUMMARY}

This study examines the diurnal variation in visually observed breaker height for 17 COSOP stations and two other sites on the coasts of the United States. The results are as follows:

1. An increase in average height in the afternoon or early evening, the expected result of a sea breeze, occurred at 88 percent of the stations in June, 94 percent in July, and 82 percent in August.

2. Differences between the largest and smallest mean heights for different hours within the day (average absolute diurnal variation) were 0.1 to 0.3 foot. The-Pacific Northwest and gulf area had the largest variation, followed by the southern Atlantic and California.

3. Observations made twice daily at two gulf locations in early summer of 1972 showed that the afternoon height was larger than the morning height 39 and 47 percent of the time, and less than the morning height 23 and 24 percent of the time. At both stations the mean afternoon wave height was slightly higher than the morning mean.

4. Correlation between absolute diumal variation and coastal exposure indicate that stations with a large sector of exposure have less frequent and smaller afternoon increases in height and period than stations with limited exposure.

5. Stations with large mean breaker heights also tend to have smaller diurnal variations in wave height.

6. An approximation for wave height that combines swell and the sea breeze-generated wave and considers the frequency of occurrence of sea breeze, gives a plausible indication of why the mean observed variations due to the sea breeze are small. 


\section{LITERATURE CITED}

BYERS, H.F., and RODEBUSH, H.R., "Causes of Thunderstorms of the Florida Peninsula," Journal of Meteorology, Vol. 5, 1948, pp. 275-280.

CLARKE, R.H., "Some Observations and Comments on the Sea Breeze," Australian Meteorology Magazine, No. 11, Melbourne, 1955, pp. 47-68.

CLARKE, R.H., "Mesostructure of Dry Cold Fronts Over Featureless Terrain," Journal of Meteorology, Vol. 18, 1961, pp. 715-735.

DARLING, J.M., "Surf Observations Along the United States' Coasts," Joumal of the Watemways and Harbors Division, ASCE, Vo1. 94, No. 1, Feb. 1968, pp. 11-21.

DAVIS, W.M., SCHULTZ, L.C., and WARD, R. deC., "An Investigation of the Sea Breeze," Harvard University Annals of Astronomical Observatory, Vo1. 21, Jan. 1890, pp. 214-264.

ESTEVA, D.C., "Diurnal Effect at Point Mugu, California from Wave Gage Data," abstract in EOS, Vol. 53, No. 4, Apr. 1972, p. 394.

FINDLATER, J., "Some Aerial Exploration of Coastal Airflow," Meteorology Magazine, Vo1. 92, 1963, pp. 231-243.

GALVIN, C.J., and SEELIG, W.N., "Surf on U.S. Coastline," Laboratory Report, U.S. Army, Corps of Engineers, Coastal Engineering Research Center, Washington, D.C., unpublished, 1969.

GALVIN, C.J., TENNEY, L.W., and SEELIG, W.N., "Differences Between LittoraI and Offshore Wave Climates," Laboratory Report, U.S. Army, Corps of Engineers, Coastal Engineering Research Center, Washington, D.C., unpublished, 1970 .

GALVIN, C.J., et al., "Nearshore Visual Wave Observations for United States" Coastlines," Laboratory Report, U.S. Army, Corps of Engineers, Coastal Engineering Research Center, Washington, D.C., unpublished, 1969.

HARRIS, D.L., "Characteristics of Wave Records in the Coastal Zone," Waves on Beaches, Academic Press, New York, 1972, pp. 1-51.

HSU, S.A., "Coastal Air-Circulation System: Observations and Empirical Mode1," Monthly Weather Review, Vol. 98, No. 7, Ju1y 1970, pp. 487-509.

KOHLER, R.R., "Effects of Coastal Exposure and Offshore Slope on Mean Height," Laboratory Report, U.S. Army, Corps of Engineers, Coastal Engineering Research Center, Washington, D.C., unpublished, 1972.

MCPHERSON, R.D., "A Numerical Study of the Effect of a Coastal Irregularity on the Sea Breeze," Journal of Applied Meteorology, Vo1. 9, No. 5, Oct. 1970, pp. 767-777. 
MOROZ, W.J., "A Lake Breeze on the Eastern Shore of Lake Michigan: Observations and Model," Jourmal of Atmospheric Science, Vol. 24, July 1967, pp. 337-355.

SONU, C.J., et al., "Sea Breeze and Coastal Processes," EOS, Vol. 54, No. 9, 1973, pp. 820-833.

U.S. ARMY, CORPS OF ENGINEERS, COASTAL ENGINEERING RESEARCH CENTER, Shore Protection Manual, $2 \mathrm{~d}$ ed., Vols. I, II and III, Stock No. 008-022-00077, U.S. Government Printing Office, Washington, D.C., 1975 .

WALLINGTON, C.E., "Convection at the Sea Breeze Front," Proceedings of the Second Conference on Cumulus Convection, Pergamon Press, 1960, pp. 119-125.

WALLINGTON, C.E., "An Introduction to the Sea Breeze Front," Schweizer Aero-Revue, Vo1. 36, No. 7, 1961, pp. 393-397.

WEXLER, R., "Theory and Observations of Land and Sea Breeze," Bulletin American Meteorological Society, Vo1. 27, June 1946, pp. 272-287.

YU, T.W., and WAGNER, N.K., "Diurnal Variation of Onshore Wind Speed Near a Coastline," Joumal of Applied Meteorology, Vol. 9, No. 5, Oct. 1970, pp. $760-766$. 



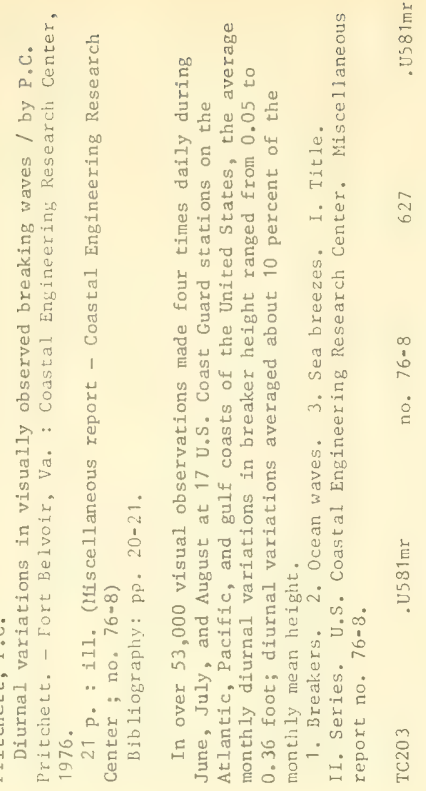

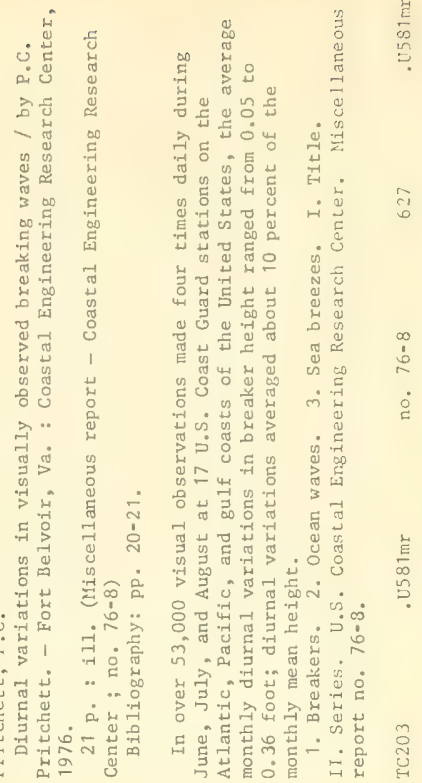

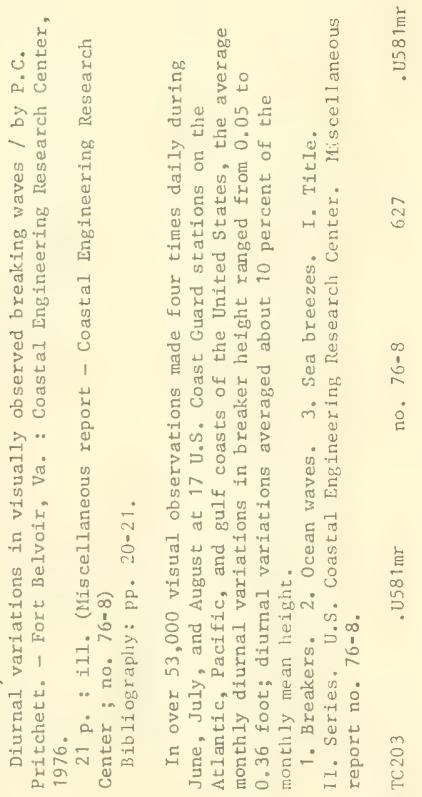

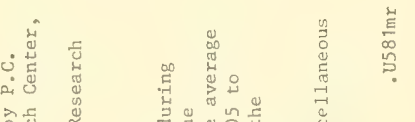

रेक्ष

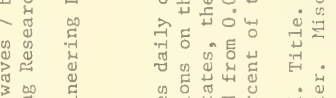

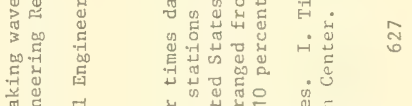

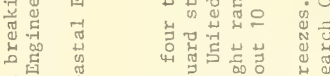

ग्व

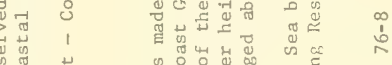

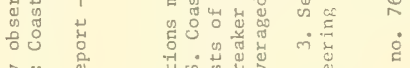

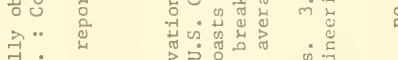

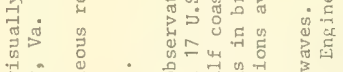

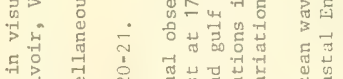

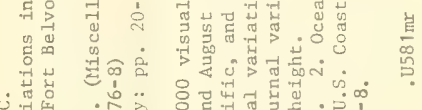

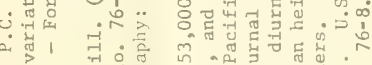

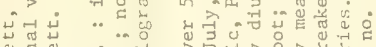

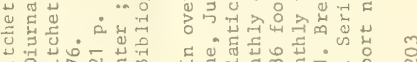

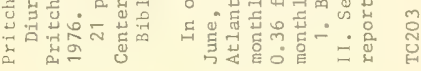





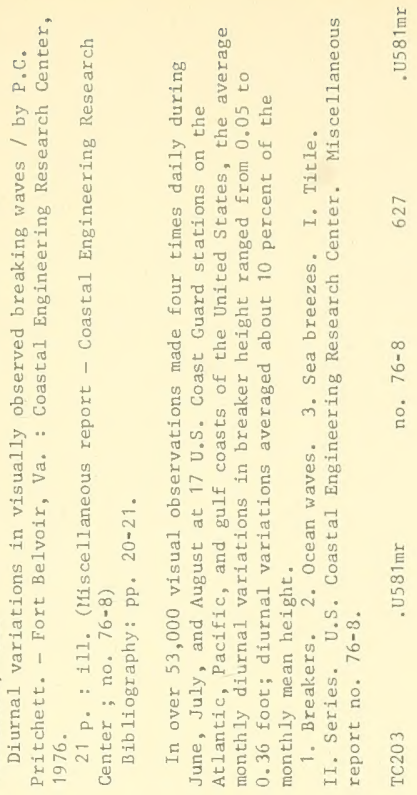

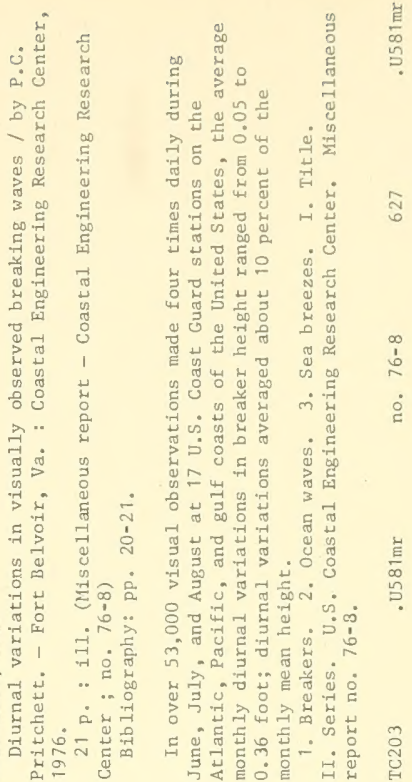

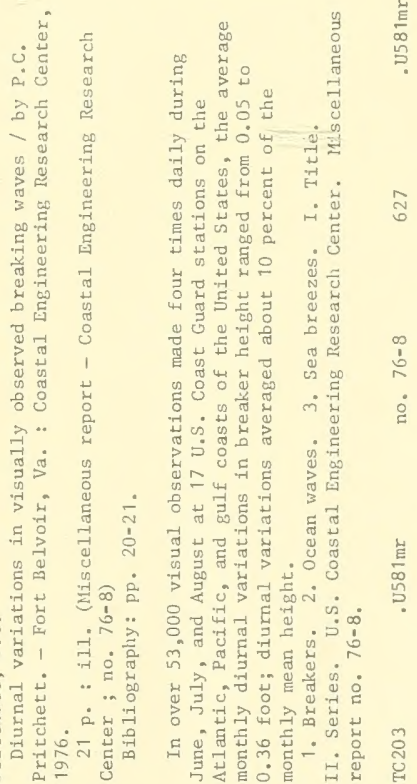

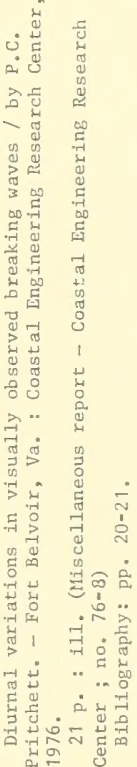

莹

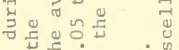

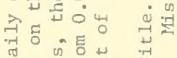

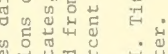

岂芯芯芯芯

क⿺辶大山

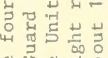

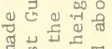

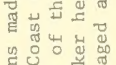

通

类

ख)

हैं

की

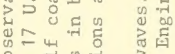

을

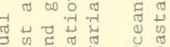

की

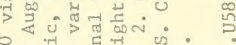

8 它出

मी

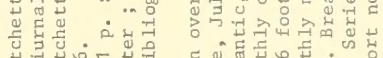

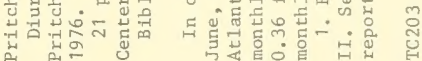




